\title{
Contents of Volume 4
}

Editorial Note

Robert Nicolaï

\section{Articles}

Linguistic changes in the Catalan spoken in Catalonia under new contact conditions

Antoni Arnal

Frequency Effects on the Morphological Conditioning of

Syllable-final /s/ Reduction in Border Uruguayan Spanish

Mark Waltermire

Why Don't All Contact Features Act Alike? Contact Features as

Enregistered Features

Anna M. Babel

Exploring the Old French Influence on Middle English

Prepositional Constructions: A Phraseological

Investigation of at need and in need

Melanie Borchers

Reappraising the Effects of Language Contact in the Torres Strait Jessica Hunter, Claire Bowern, and Erich Round

A Systematic Comparison of Factors Affecting the Choice of

Matrix Language in Three bilingual Communities

Diana Carter, Margaret Deuchar, Peredur Davies,

Maria del Carmen Parafita Couto

Manifestations of areal Convergence in rural Belarusian

Spoken in the Baltic-Slavic Contact zone

Björn Wiemer, Aksana Erker

Who Changes Language? Bilingualism and structural Change in Burma and the Reef Islands

Ashild Nass \& Mathias Jenny

The Influence of English on the History of Hindi relative Clauses

$250-268$ Vandana Puri 
Origins of a Preposition: Chinese Pidgin English long and its Implications for Pidgin Grammar

Michelle Li

\section{Book Reviews}

Ilya Jakubovich, 2010. Sociolinguistics of the Luvian language

Daniel Petit

Hughson, Jo-anne. Diversity and changing values in address

John M. Lipski

Carole de Féral. Le nom des langues III. Le nom des langues en Afrique sub-saharienne: pratiques, dénominations, catégorisations/Naming languages in Sub-Saharan Africa:

Practices, Names, Categorisations

Mauro Tosco

Yaron Matras. Romani in Britain: The Afterlife of a Language Victor A. Friedman

Robert Nicolaï. La construction du sémiotique. Sur les dynamiques langagières et l'activisme des acteurs de la communication Jean Léo Léonard

Petr Zima (ed.) in cooperation with Norbert Cyffer, M. Holubová, Herrmann Jungraithmayr, Rudolf Leger, Henning Schreiber, Anne Storch, and Ulrike Zoch. The verb and related areal features in West Africa. Continuity and Discontinuity within and across Sprachbund Frontiers Zygmunt Frajzyngier

List of Referees / Liste des referees 